H A R VAR D

\title{
Brides for Sale: Cross-Border Marriages and Female Immigration
}

Daiji Kawaguchi Soohyung Lee

\section{Working Paper}

12-082

March 13, 2012 


\title{
Brides for Sale:
}

\section{Cross-Border Marriages and Female Immigration*}

\author{
Daiji Kawaguchi \\ Department of Economics \\ Hitotsubashi University \\ kawaguch@econ.hit-u.ac.jp
}

\author{
Soohyung Lee \\ Department of Economics and MPRC \\ University of Maryland \\ LeeS@econ.umd.edu
}

This Draft: March 2012

First Draft: March 2011

\begin{abstract}
Every year, a large number of women migrate as brides from developing countries to developed countries in East Asia. This phenomenon virtually did not exist in the early 1990s, but foreign brides currently comprise 4 to 35 percent of newlyweds in these developed Asian countries. This paper argues that two factors account for this rapid increase in "bride importation": the rapid growth of women's educational attainment and a cultural norm that leads to low net surplus of marriage for educated women. We provide empirical evidence supporting our theoretical model and its implications, using datasets from Japan, Korea, Taiwan, and Singapore.
\end{abstract}

JEL Classification: A12, J12, J61

Keywords: Immigration, Marriage, Sex Ratio Imbalance, International Marriages, Crossborder marriages, Assortative Matching

* We thank Lisa Dettling, Jihye Kam, Seon Young Yoon, Akiko Nasuda and Akiko Togawa for their excellent research assistance. We have benefited from discussions with Kenn Ariga, Marianne Bertrand, Richard Freeman, Dan Hamermesh, John Ham, Judith Hellerstein, Takao Kato, Melissa Kearney, Jeanne Lafortune, Shelly Lundberg, Chiaki Morguchi, Gary Richardson, Al Roth, Aloysius Siow, Nina Smith, John Strauss, John Wallis, Yoram Weiss, Junsen Zhang, and seminar participants at the University of Maryland, UC-Irvine, the Workshop on Empirical Analysis of Family Economics (Denmark), the Summer Econometric Society Meeting, University of Tokyo, Hitotsubashi University, Korea University, Nagoya City University, and the Transpacific Labor Seminar. 


\section{Introduction}

Every year, a large number of women migrate to developed countries in East Asia as brides. This phenomenon virtually did not exist in the early 1990s, but foreign brides currently comprise 4 to 35 percent of newlyweds in Japan, South Korea (hereafter Korea), Taiwan, and Singapore. ${ }^{1}$ Surprisingly, during this period, there is no sign of raw sex ratio imbalance in these countries; if anything, the sex ratio favors men. The balanced sex ratio in these countries and the large influx of foreign brides coincide with an unprecedented drop in marriage rate among women, particularly educated women in these East Asian countries. ${ }^{2}$ Furthermore, the majority of these foreign brides have different ethnicities from their husbands and have no history of visiting or working in their destination country prior to marriage (Yang and $\mathrm{Lu}$ (2010)). For these reasons, foreign brides generally have a limited understanding of the destination country as well as a low ability to use the destination language. The large inflow of female marriage migrants has various socioeconomic effects on these countries, such as human capital accumulation, ethnic and sex composition, and assimilation issues.

What factors are responsible for this drastic change in the East Asian marriage markets? In this paper we suggest that this demographic change is accounted for by a drastic improvement of women's labor market opportunities together with slowly changing cultural norms determining a person's net gains from marriage. By cultural norms, we mean a set of common expectations affecting gains from marriage, such as what is the ideal amount of time for a husband to do household chores and what is the ideal amount of service a wife should provide to her parents-in-law. Consider a "traditional" society where cultural norms dictate that women are expected to take care of all household chores and care for parents-in-law, while men are not. If that society has a large degree of labor market discrimination against woman, then an educated woman may be willing to get married and assume the traditional role of a married woman because she has little opportunity other than home production. Now suppose that that society with traditional cultural norms

\footnotetext{
${ }^{1}$ In Hong Kong, the information on foreign brides is not publically available, but we expect the prevalence will be similar to Taiwan. For example, only less than 2 percent of H.K. grooms married brides from China in 1991, but the figure rapidly grew in the 2000s and reached 39 percent in 2005.

${ }^{2}$ This phenomenon has received much attention from the media around the world. Examples include the New York Times article of February 22, 2007 by Norimitsu Onishi and the lead article "Asia's Lonely Heart" in the Economist (August, 20-26 2011).
} 
experiences a great improvement regarding women's labor market opportunity. Then an educated woman may no longer be willing to accept the traditional role of a married woman because she can work in the labor market and support herself without getting married. If the raw sex ratio is balanced, this means that improvement in women's labor market opportunity leads to effective sex ratio imbalance, unless the cultural norms governing marriage gain change accordingly. Therefore, men less preferred by women (e.g., uneducated men) may not find a spouse within the society, and thus they turn to another country to find their brides.

Why would not the cultural norms sufficiently respond to the improvement in women's socioeconomic status relative to men? Suppose that all men prefer marrying a native woman to being single or marrying a foreign woman. In our example above, standard marriage models following Becker (1973) predict that, in equilibrium, men will transfer more marriage gains to women to compensate for the increase in their outside options due to the reduction of gender discrimination. Therefore, the rise in women's socioeconomic status may not cause a large demand for foreign brides, different from what these developed East Asian countries have been experiencing. We suspect that a limited commitment problem may account for this puzzle. ${ }^{3}$ For example, suppose that an educated woman prefers marrying an uneducated man to remaining single if the uneducated man is entirely in charge of home production; otherwise, she prefers being single. In a real marriage market, however, it is not possible write a binding contract requiring the man to do all the home production after marriage. If divorce is costly, then the educated woman may expect that remaining single is on average better than marrying an uneducated man.

We model the story sketched above in a simple two-sided matching framework. In the spirit of limited commitment, we use a non-transferability utility model where an individual's socioeconomic status (referred to as education) and payoff from marrying a certain type of person are exogenously determined. In our model, cultural norms governing a person's net gains from marriage are accounted for by two statistics: the number of “modern” men who suffer less from participating in home production than traditional men, and the number of career-oriented women who have more utility from market work than other women. Our model shows that a rapid improvement in women's labor market

\footnotetext{
${ }^{3}$ See Lundberg and Pollak (2007) for further discussion of limited commitment in family formation.
} 
opportunity causes a greater number of career-oriented educated women to remain single unless the cultural norms change fast enough to compensate for the rise in women's reservation utility. The increase in women's singlehood leads to the importation of foreign brides by men who are less preferred by women, if the men prefer marrying a foreign woman to remaining single.

We analyze macro and administrative datasets from Japan, Korea, Taiwan, and Singapore and find a negative relationship between the gender gap of educational attainment and the fraction of men marrying a foreign bride, consistent with our model prediction above. We also test additional model implications with the data. First, our model predicts a positive correlation between a woman's education and her singlehood. In the data, a college-educated woman is 50 percent to 200 percent more likely to remain single than her counterpart with no tertiary degree. Second, our model predicts that a groom who has a foreign bride has lower socioeconomic status than another groom whose bride is a native woman. Our empirical analysis shows that, all else being equal, a man who is a high school graduate is about 6 to 10 percent more likely to marry a foreigner than a man with a college degree. Relative to white-collar workers, a man working in the agricultural sector or at a low-skilled job is more likely to marry a foreigner.

This paper suggests that a country's development and gender equality can significantly affect the marriage market by effective sex ratios and that their impact can be transmitted to other countries through marriage migration. An important question is what countries will be "at risk" if a country demands foreign brides. Estimating a gravity model, we find that the number of women a country sends to the East Asian countries as marriage migrants is significantly correlated with its income relative to the destination country, geographical distance, and its trade volumes with the destination country. These three factors account for over a quarter of the data variations observed in Korea, Japan, and Taiwan. By examining the way a man chooses the country from which he takes his bride, we find an interesting phenomenon of positive sorting along occupation. For example, all else being equal, a Korean farmer is more likely to choose a Vietnamese bride, who more often has experience in farming production compared to a Chinese or Filipino bride. Finally, another important question for policy implications is whether a female marriage migrant is positively or negatively selected in terms of human capital. By examining the 
census data of the home countries of female marriage migrants, we find that these brides are more educated than their counterparts in their home country and overseas female workers from their countries. This finding suggests that marriage immigration can raise a concern over "brain drain" in their home countries.

This paper integrates three economics literatures. The first is the rich literature on marriage. Following a pioneering work by Becker (1973), many researchers theoretically and empirically have studied the clearing mechanisms in marriage markets and underlying preferences of agents (see for review, Weiss (2000)). Particularly, our paper is related to the studies on sex ratio imbalance and its consequences in marriage markets (e.g., Abramitzky et al. (2011), Angrist (2002), Edlund (1999), Foster and Rosenzweig (2001), Lafortune (2011), Wei and Zhang (2011)). Our paper contributes to these studies by suggesting that the gender gap reduction in socioeconomic status can lead to an "effective" sex ratio imbalance and that this imbalance can spill over across countries through marriage migration.

The second body of literature studies the interaction between work, marriage, and family options (see Goldin (2006) for review). Specifically, Fernández, Fogli and Olivetti (2004) provide a dynamic model that provides intergenerational correlation in terms of men's attitude toward having a working wife. According to their model, we can explain the East Asian phenomenon studied in this paper as follows. In these countries, governments' policies, such as universal education and change in labor regulations, may directly increase gender equality in terms of education and labor market outcomes. Due to their intergenerational transmission, cultural norms change with an S-shaped speed rate, meaning changing slowly at first, drastically in the middle, and finally settling down. Compared to the U.S., these developed East Asian countries experienced a remarkable increase in educational attainment and also economic development overall (i.e., beginning stage of the change); therefore, their cultural norms will require more time to catch up in terms of improvement in the gender gap in education/labor market opportunity.

While the literature on marriage immigration is quite new to economics, ${ }^{4}$ sociologists and policy-oriented research institutions have studied the prevalence and

\footnotetext{
${ }^{4}$ The recent economics literature on marriage immigration per se includes an analysis of Nielsen et al. (2009). They study the impact of a Danish policy change that bans an immigrant from bringing a spouse from his/her
} 
potential determinants of foreign brides and conducted interviews to examine who married a foreign wife and why (for reviews, Yang and Lu (2010)). In general, research indicates that men with low socioeconomic status, particularly famers, have difficulty finding a spouse and thus resort to marrying a foreign woman (Lee (2008), Park and Choi (2008) in Korea, Sato (1988) in Japan, Wang and Chang (2002) in Taiwan). As factors explaining the increase in foreign brides, some research focuses on the skewed sex ratio in rural areas since a farmer is much more likely to marry a foreigner (Morgan and Hoffmann (2007)); another study indicates that a man marries a foreign wife because such a woman is more willing to assume the role of a traditional wife: household production and helping care for parents-in-law (Sato (1988)). This paper differs from these existing studies in several dimensions. We provide a simple yet unified theoretical framework to explain the increase in number of foreign brides, female educational attainment, and extent of singlehood, particularly among educated women. Second, we use various datasets from multiple countries and find common patterns instead of using one country's dataset. Moreover, the gravity model analysis we use to examine what countries would be "at risk" in exporting women as brides is new to the literature.

The rest of the paper is organized as follows. Section 2 presents background information about cross-border marriages in East Asia. Section 3 presents a theoretical framework, and Section 4 shows our empirical analysis. Section 5 examines policy implications of the large influx of marriage migration, and Section 6 concludes the paper.

\section{Institutional Backgrounds}

We use aggregate statistics from marriage records in Japan, Korea, Taiwan, and Singapore and plot the fraction of newlywed men whose bride is a foreigner over time (Table 1). Korea has shown the most rapid growth in marriages between citizen grooms and non-citizen brides, increasing from less than 1 percent of all newlyweds in 1991 to 8 percent in 2007. In Taiwan, the marriages involving non-Taiwanese and non-Chinese

home country on immigrants' educational attainment. Nicely summarized in their work, many non-Western immigrants in Scandinavia choose their spouses from their country of origin and bring them to their country of residence. The marriage immigration in East Asia that we study is different from that in Scandinavian countries in two respects. One is that natives, instead of immigrants, bring a spouse from a foreign country; the other is that almost all marriage migrants in East Asia are women, whereas a significant fraction of marriage immigrants are men. 
brides accounted for 6 percent of newlyweds in 1998, peaking in 2004 at 13 percent, and then stabilizing at about 5 percent in 2007 (see details in Appendix 2.4). In Singapore, international marriages comprised 30 to 40 percent of total marriages between 1999 and 2009.

Table 1 Summary of the Environment

\begin{tabular}{|c|c|c|c|c|c|c|c|}
\hline \multirow[b]{2}{*}{ Year } & \multicolumn{2}{|c|}{$\begin{array}{l}\text { Natives Marrying a } \\
\text { foreigner }^{\text {a) }}\end{array}$} & \multicolumn{2}{|c|}{ College Educated ${ }^{\mathbf{b})}$} & \multicolumn{2}{|c|}{$\begin{array}{c}\text { Diff. in \% } \\
\text { Unmarried } \\
\text { (College vs. Not) }^{c}\end{array}$} & \multirow[t]{2}{*}{$\begin{array}{c}\text { Sex } \\
\text { Ratio }^{d)}\end{array}$} \\
\hline & $\begin{array}{c}\text { Men } \\
\% \\
(1)\end{array}$ & $\begin{array}{c}\text { Women } \\
\% \\
(2)\end{array}$ & $\begin{array}{l}\text { Men } \\
\% \\
(3)\end{array}$ & $\begin{array}{l}\text { Men - } \\
\text { Women } \\
\text { \%pts. } \\
\text { (4) }\end{array}$ & $\begin{array}{l}\text { Men } \\
\text { \%pts. } \\
(5)\end{array}$ & $\begin{array}{l}\text { Women } \\
\text { \%pts. } \\
\text { (6) }\end{array}$ & \\
\hline \multicolumn{8}{|c|}{ Panel A. Japan } \\
\hline 1992 & 2.6 & 0.9 & 36.1 & -1.6 & -3.2 & 3.3 & 102.1 \\
\hline 1997 & 2.7 & 1.0 & 39.0 & -4.2 & -4.0 & 2.4 & 102.6 \\
\hline 2002 & 3.7 & 1.1 & 41.6 & -6.5 & -5.0 & 1.7 & 102.3 \\
\hline 2007 & 4.5 & 1.2 & 47.9 & -7.0 & -3.4 & 1.0 & 102.8 \\
\hline \multicolumn{8}{|c|}{ Panel B. Korea } \\
\hline 1990 & 0.2 & 1.0 & 31.0 & 13.2 & -2.5 & 3.5 & 104.5 \\
\hline 1995 & 2.6 & 0.8 & 39.5 & 12.2 & -4.9 & 3.4 & 103.9 \\
\hline 2000 & 2.2 & 1.5 & 46.8 & 8.5 & -8.5 & 4.1 & 104.0 \\
\hline 2005 & 10.2 & 4.2 & 58.1 & 4.4 & -6.8 & 7.3 & 103.4 \\
\hline \multicolumn{8}{|c|}{ Panel C. Singapore } \\
\hline 2000 & 24.3 & 10.9 & 39.4 & 3.0 & -4.6 & 10.8 & 96.6 \\
\hline 2010 & 35.0 & 13.2 & 63.3 & -2.6 & -10.5 & 7.8 & 94.5 \\
\hline \multicolumn{8}{|c|}{ Panel D. Taiwan e) } \\
\hline 1998 & 5.9 & 1.2 & 25.1 & 1.4 & - & - & 105.0 \\
\hline 2000 & 10.5 & 1.3 & 31.9 & 0.1 & - & - & 104.8 \\
\hline 2005 & 8.6 & 2.3 & 49.8 & -3.8 & - & - & 103.4 \\
\hline 2008 & 4.0 & 2.1 & 55.4 & -4.2 & - & - & 102.2 \\
\hline
\end{tabular}

Note: See Section 2 of the Appendix for sources and definitions for each country.

a) Fraction of citizen grooms who married a foreign bride (column 1) and that of citizen brides who married a foreign groom (column 2).

b) Fraction of college educated among men whose age is between 20 and 39 (column 3). The numbers in column 4 are the fraction of college educated men among men minus the fraction of college educated women among women in age 20 to 39.

c) We use the population whose age is between 30 and 39 in order to exclude individuals who are in school. For each sex and education level, we compute the fraction of unmarried people. We then report the difference in this fraction between college educated and non-college educated.

d) We use the population whose age is between 20 and 39. Sex ratio refers to the number of men divided by women times 100 .

e) Foreign brides exclude Chinese from Mainland China, H.K, and Macao. The drop in the fraction of foreign brides in 2005 and 2008 is due to immigration policy changes since 2000. The immigration policy changes include language sufficiency tests, interviews, and no issuance of a spouse visa if the age gap between a groom and bride is over 20 years (see Kim et al (2010) for details). 
Technically speaking, a foreign bride in a marriage record can be an economic migrant who happened to marry a citizen groom, and the most of the marriage records do not provide the information distinguishing marriage migrants and economic migrants among foreign brides. However, additional surveys suggest that a significant fraction of foreign brides are marriage migrants. For example, in Korea, about 79 percent of nonKoreans women (including Korean-Chinese) who married Korean men came to Korea because of marriage; only 7.3 percent came to Korea for work and got married (Seol et al. (2009)). Moreover, a substantial number of foreign brides met their spouses in connection with a "marriage tour" (Wang and Chang (2002) and Korea (2005)), which takes the following procedure. ${ }^{5}$

A marriage broker recruits men looking for spouses abroad. ${ }^{6}$ We refer to the country where men reside as the host country. Another marriage broker recruits a group of women outside the host country, such as China, Vietnam, or the Philippines. We refer to the country where these women reside as the source country. When a sufficient number of men and women are recruited, the two brokers contact one other, and the broker in the host country organizes a group tour of source country for the men. The men and women have a few group dating sessions, during which they decide whom to marry. When they find their mate, they file the necessary legal documents to be recognized as a married couple in the bride's country. Then the groom goes back to his country and applies for marriage certificates in his country, so that his bride can get a visa to enter his country as a legal immigrant.

Grooms generally pay for brokerage fees, legal processing fees, and payments to their bride's family. The total costs are estimated approximately 10,000 U.S. dollars. ${ }^{7}$ Until marriage, interaction between men and women is minimal because the process is rapid

\footnotetext{
${ }^{5}$ Seol et al. (2009) report that 27 to 38 percent of female marriage migrants found their husbands through marriage brokers, whereas Park and Choi (2008) found that 53 percent of female marriage migrants used marriage brokerage firms.

${ }^{6}$ Different from countries like the US, obtaining legal immigrant status for non-citizens through cross-border marriages is relatively easy in these two economies, and there is no legal restriction on the business of international marriage agencies. This is not the case in the US. In fact, because of the upsurge in international marriages through international marriage agencies, US legislators enacted the International Marriage Broker Regulation Act of 2005 and started to restrict the issuance of K-1 fiancée visas.

${ }^{7}$ In Japan, the cost ranges from 10,000 to 15,000 US dollars (authors' survey of web sites). Wang and Chang (2002) reports 9,100 US dollars as the average fee charged by agencies in Taiwan that brokered the marriage of Taiwanese men and Vietnamese women in 2000. In Korea, the cost ranges roughly from USD 8,000 to 12, 000 (Presidential Committee of Social Inclusion, 2005).
} 
(about 10 days for the marriage tour and 6 months until the women's immigration) and communication takes place through interpreters hired by the marriage brokers because the man and woman often do not speak a common language.

\section{Theoretical Framework}

\subsection{Setting}

We assume that there are the same number of men and women in this country and normalize the population size of each sex as 1 . In each sex, there are three types of agents in a country of interest: a modern $H$-type, a traditional $H$-type, and an $L$-type. $H$ - and $L$ type indicate whether a person has a high $(H)$ or low $(L)$ socioeconomic status. In sex $G \in\{m, w\}$ where $m$ and $w$ denote men and women, respectively, the $h_{G}$ fraction of agents are $H$-type, and the fraction of modern agents among the $H$-type is $\alpha_{G}$ with $0 \leq \alpha_{G} \leq 1$. Thus, $\left(1-\alpha_{G}\right) h_{G}$ fraction of agents is traditional, and the remaining $1-h_{G}$ are $L$-type. A man in the country of interest can find a large number of women from the rest of the word (herein foreigner) who want to marry him and immigrate to his country, whereas a woman in the country of interest does not have that option. ${ }^{8}$

We assume exogenous payoffs from marriage depending on men's and women's types, in the spirit of the non-transferable utility assumption (see Smith (2006)). In our model, two agents in each type have the same preferences regarding the spouse's type, and an agent is indifferent between two partners as long as their type is the same. All women prefer a modern $H$-type man $m_{M H}$ the most, followed by a traditional $H$-type man $m_{T H}$, and then an $L$-type man $m_{L}$. The only difference among women is that a modern $H$-type woman prefers remaining single to marrying a $L$-type man, while the rest of women prefer marrying an $L$ type man to remaining single. In contrast, all men most prefer a woman who is of the same type as their own the most, and a foreigner $w_{F}$ the least. Besides the two types, a modern $H$-type man prefers a traditional $H$-type woman $w_{T H}$ to an $L$-type woman $w_{L}$; a traditional $H$-type man prefers $w_{L}$ to a modern $H$-type woman $w_{M H}$; and an $L$-type man prefers $w_{T H}$ to $w_{M H}$ (see Table 2).

\footnotetext{
${ }^{8}$ We introduce this assumption purely for simplification purposes. Our model implications remain the same if international migration from a developed country to a less developed country reduces a person's payoffs from marriage. Moreover, this assumption is realistic in that a foreign man with high socioeconomic status whom a modern $H$-type woman would like to marry (e.g., a lawyer in the U.S.) may no longer be an $H$-type when he migrates to the woman's home country due to imperfect transferability of human capital.
} 
Table 2 Summary of the Environment

\begin{tabular}{lcc}
\hline \hline Type & Size & Preference Ranking \\
\hline Men & & \\
Modern H-type $\left(m_{M H}\right)$ & $\alpha_{m} h_{m}$ & $w_{M H}>w_{T H}>w_{L}>w_{F}>\varnothing$ \\
Traditional H-type $\left(m_{T H}\right)$ & $\left(1-\alpha_{m}\right) h_{m}$ & $w_{T H}>w_{L}>w_{M H}>w_{F}>\varnothing$ \\
L-type $\left(m_{L}\right)$ & $1-h_{m}$ & $w_{L}>w_{T H}>w_{M H}>w_{F}>\varnothing$ \\
Women & & \\
Modern H-type $\left(w_{M H}\right)$ & $\alpha_{w} h_{w}$ & $m_{M H}>m_{T H}>\varnothing>m_{L}$ \\
Traditional H-type $\left(w_{T H}\right)$ & $\left(1-\alpha_{w}\right) h_{w}$ & $m_{M H}>m_{T H}>m_{L}>\emptyset$ \\
L-type $\left(w_{L}\right)$ & $1-h_{w}$ & $m_{M H}>m_{T H}>m_{L}>\emptyset$ \\
Foreigners $\left(w_{F}\right)$ & 1 & $m_{M H}>m_{T H}>m_{L}>\emptyset$ \\
\hline \hline
\end{tabular}

Note: $\varnothing$ denotes remaining single.

\section{Role of Culture and Household Production}

Our assumptions as to agents' preferences capture some realities of East Asian marriage markets and the empirical findings in economics literature on marriage. As for men's preferences, we incorporate two features. One is the empirical literature reporting that men value women's education only up to the point where women's educational attainment does not surpass men's own educational attainment (see Fisman et al. (2006) for supporting evidence for the U.S. and Lee (2011) for similar findings for Korea). The other feature is the heterogeneity among men in supporting their wives' labor market participation. We assume that a woman's likelihood of participating the labor market after her marriage is the highest if she is a modern $\mathrm{H}$-type, followed by a traditional $\mathrm{H}$-type, and then $L$-type, and that all men, except for a modern $H$-type, prefer a homemaker to a working wife, unless women are of the same type as theirs. Finally, the assumption that a modern $H$-type woman prefers singlehood to marrying an $L$-type man captures the fact that in East Asia, married women mostly bear the burdens of household production, such as childcare and caring for parents-in-law, regardless of their and their husbands' labor market opportunities. This fact suggests a possible reason for the large influx of female migrants in the developed East Asian countries but not in other developed countries. That is, in a nonAsian culture, a marriage between a modern $H$-type woman and a $L$-type man is acceptable to the woman because the $L$-type man can contribute more to the household production than an $H$-type man and thus the former can compensate for his low contribution to household budget to a certain extent. In contrast, due to certain social norms or cultural 
differences, an $L$-type man's contribution to household production is too low to make a marriage with him acceptable to a modern $H$-type woman.

We provide below additional evidence that supports the cultural norm affecting individual's marital preferences. We first focus on the rapid development of East Asian countries as compared to developed countries in North America and Western Europe. Figure 1 shows the fraction of college graduates in each sex and cohort in Japan, Korea, and the U.S. The figure shows that educational attainment, measured by the fraction of college graduates, has increased the fastest in South Korea, followed by Japan, and the U.S.

Figure 1 Fraction of College Graduates by Sex and Cohort

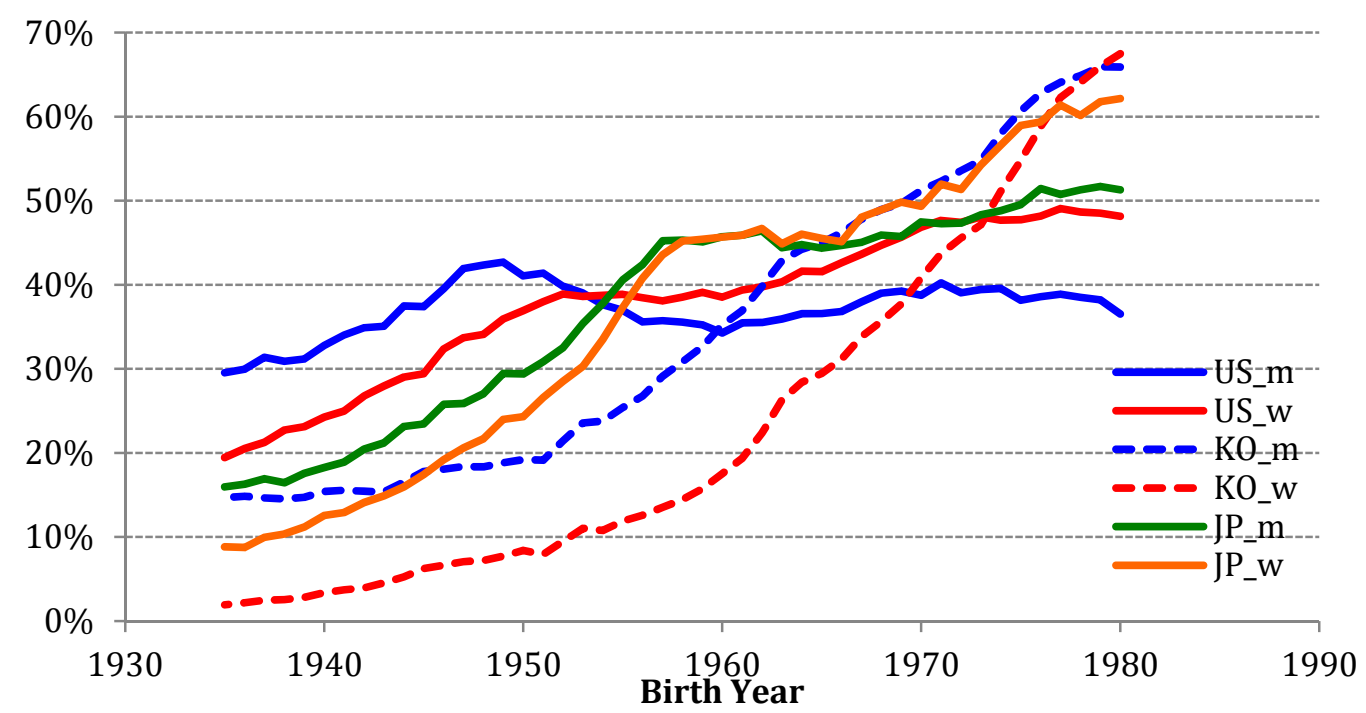

Note: U.S. Population Census (2010), South Korean Population Census(2010), Japanese Employment Status Survey (2007). US_m, KO_m, and JP_m show the fraction of college educated among men (women) in each cohort in the United States, South Korea, and Japan, respectively. Similarily, US_w, KO_w, and JP_w refer to the fraction of college graduates among women in each of countries.

This implies that a woman in Korea is more likely to have parents-in-law who are much less educated than she is. Thus, the parents-in-laws in Korea are more likely to maintain a traditional view of marriage than those in the U.S., which puts less value on a wife's socioeconomic status. Therefore, even if there were the same number of educated men in Korea and the U.S., Korea would have fewer "modern educated men," that is, educated men who (and whose parents) support the market activity of their wives (daughters-in- 
law). ${ }^{9}$ Note that this intergenerational transmission is intensively studied by Fernández et al. (2004) to explain the S-shaped increase in female labor market participation rate in the U.S.

Table 3 Daily Time Use of Married Individuals in Korea, Japan and the US. Unit: Minutes per day

\begin{tabular}{|c|c|c|c|c|c|c|c|c|c|}
\hline & \multicolumn{3}{|c|}{$\underline{\text { Korea }}$} & \multicolumn{3}{|c|}{$\underline{\text { Japan }}$} & \multicolumn{3}{|c|}{$\underline{\text { U.S. }}$} \\
\hline & M & $\mathrm{H}$ & $\mathrm{L}$ & M & $\mathrm{H}$ & $\mathrm{L}$ & M & $\mathrm{H}$ & $\mathrm{L}$ \\
\hline \multicolumn{10}{|l|}{ Wife: Coll. } \\
\hline - Husband: Coll. & 130 & 308 & 247 & 164 & 365 & 287 & 224 & 250 & 336 \\
\hline - Husband: Non Coll. & 134 & 305 & 240 & 196 & 330 & 285 & 228 & 239 & 345 \\
\hline \multicolumn{10}{|l|}{ Wife: Non Coll. } \\
\hline - Husband: Coll. & 137 & 277 & 274 & 137 & 332 & 328 & 144 & 275 & 384 \\
\hline - Husband: Non Coll. & 173 & 250 & 261 & 166 & 297 & 322 & 160 & 257 & 376 \\
\hline \multicolumn{10}{|l|}{ Husband: Coll. } \\
\hline - Wife: Coll. & 333 & 52 & 258 & 449 & 51 & 320 & 320 & 161 & 358 \\
\hline - Wife: Non Coll. & 332 & 38 & 287 & 450 & 44 & 323 & 289 & 159 & 379 \\
\hline \multicolumn{10}{|l|}{ Husband: Non Coll. } \\
\hline - Wife: Coll. & 345 & 49 & 240 & 366 & 48 & 379 & 283 & 162 & 387 \\
\hline - Wife: Non Coll. & 304 & 40 & 303 & 334 & 44 & 392 & 221 & 155 & 426 \\
\hline
\end{tabular}

Note: M - market production, H - household production, L - leisure. Korea time use survey 2009, Japan time use survey 2006, and American time use survey 2009 are used. College graduate includes graduates from junior colleges. Sampling weight is applied. For Korea, M includes work and work related activities. H includes housework, child-care, caring and nursing. L includes TV, socializing, relaxing and recreation, sports, exercise and recreation, religious and spiritual activities, telephone calls, and traveling. For Japan, M includes work, schoolwork, commuting to/from school or work, studying and researching. H includes housework, child-care, caring and nursing, and shopping. L includes TV, radio, reading, rest and relaxation, hobbies and amusements, sports, volunteer and social activities, and social life. For the U.S., M includes working and work-related activities, and educational activities. $\mathrm{H}$ includes household activities, caring for and helping household members, caring for and helping non-household members, consumer purchases, professional and personal care services, household services, and government services and civic obligations. L includes socializing, relaxing and recreation, sports, exercise and recreation, religious and spiritual activities, telephone calls, volunteer activities, and traveling.

\footnotetext{
${ }^{9}$ In East Asia, parents-in-law play an important role in a married woman's labor market participation. In East Asia, there are many activities involving extended families, which typically require a married woman to serve her parents-in-law. Suppose that a working mother has parents-in-law who demand all the services that are tra ditionally given by a daughter-in-law (e.g., visiting them every weekend and serve meals). Then, the working mother not only has to work for a full-time job, taking care of a child (because her husband's contribution to $h$ ousehold production will be minimal), and also needs to take care of her in-laws. Therefore, her benefit from participating in a labor market can be much low as compared the case where she had modern parents-in-law who do not demand much of services from her.
} 
Next, we analyze micro datasets of time use surveys to present suggestive evidence for our argument on cultural norms. Table 3 tabulates the average minutes spent on each activity per day, including weekends, in Japan, Korea, and the U.S. ${ }^{10}$ We want to highlight the finding that in Japan and Korea, the amount of market work for married women remains stable regardless of their educational attainment. In contrast, in the U.S., collegeeducated married women spend about 40 to 50 percent more time on market work than married women with college degrees. This finding implies that even if a woman is educated, after her marriage she may need to forgo her labor market opportunity more often in Korea and Japan compared to the U.S. Therefore, overall, the gains from marriage of women with high socioeconomic status may be smaller in Japan and Korea (and other developed East Asian countries) than in the U.S. (and other western developed countries). The second point we want to highlight is that a woman appears not to gain much from "marrying down." We consider the amount of leisure time as a private consumption of a married woman, thus positively correlated with her net gains from marriage. In the U.S., a college graduate woman whose husband does not have a college degree spends more time on leisure compared to another college graduate who married a college graduate man. In contrast, the former spends less or an equal amount of time on leisure than the latter in Korea and Japan.

\subsection{Stable Matching}

To analyze the marriage market clearing in our model, we use stable matchings in which there is no pair of a man and woman who prefer marrying each other instead of their current spouses (Roth and Sotomayor (1990)).

Remark 1: In any stable matching, all $H$-type men and women who are of either traditional $H$-type or $L$-type get married to a citizen spouse. $L$-type men marry either a citizen woman or foreigner, but do not remain single. Modern $H$-type women either marry an $H$-type man or remain single.

The proof is straightforward. Suppose that in a stable matching, an $H$-type man is single. Given the balanced sex ratio among natives and no possibility of importing foreign men as grooms, there is at least one native woman who remains single. Since all native

\footnotetext{
${ }^{10}$ The sampling weight that assigns about 5 times larger weight on a Saturday or a Sunday than on a weekday are used to obtain daily average of time spend on each activity.
} 
women prefer marrying an $H$-type to remaining single, the $H$-type man and a native woman will form a blocking pair, and thus the matching cannot be stable. Likewise, a matching that leads to a woman of either traditional $H$-type or $L$-type remaining single cannot be stable. This is because-given the balanced sex ratio among natives-some native men either remain single or marry a foreigner in that matching. However, all men prefer marrying a native woman to remaining single or marrying a foreigner. Therefore, those men and single women will form blocking pairs. Since $L$-type men prefer marriage to singlehood and there is an unlimited supply of foreign brides, all $L$-type men get married. Finally, some modern $H$-type women may remain single depending on market conditions because they prefer singlehood to marrying an $L$-type man.

With these remarks in hand, we can calculate the demand for non-citizen women.

Theorem 1 (Demand for Foreign Brides) The fraction of men who marry a foreigner is the same across stable matchings. This demand for foreign brides is $\max \left\{0, \alpha_{w} h_{w}-\alpha_{m} h_{m}\right\}$. Proof. (see Appendix)

Corollary 1 (Gender Gap in Education and Demand for Foreign Brides) Let $\rho=h_{m}-h_{w}$, which measures the gender gap in socioeconomic status. For given $\alpha_{m}$ and $\alpha_{w}$, the fraction of men marrying a foreigner weakly decreases in $\rho$.

Corollary 2 (East Asian vs. Non-Asian Marriage Markets) Let $\gamma=\alpha_{w} / \alpha_{m}$, which is the ratio of modern women to modern men among $H$-type. The demand for foreign brides weakly increases in $\gamma$ given $h_{m}$ and $h_{w}$. We can characterize a developed East Asian country as a market with a higher $\gamma$, compared to non-Asian developed country. The higher $\gamma$ in East Asia may be due to the division of household work described in the previous subsection.

Based on these results, we arrive at the following empirical implications of our model:

(I.1) Demand for foreign brides weakly increases in demand for foreign grooms

(I.2) Narrowing gender gap of educational attainment increases the demand for foreign brides.

(I.3) An $L$-type man is (weakly) more likely to marry a foreigner than an $H$-type man.

(I.4) An $L$-type woman is (weakly) more likely to get married than an $H$-type woman. 


\subsection{Discussions}

We simplify our theoretical model in various respects. For example, we neither analyze an agent's endogenous choice of education in response to marriage market outcomes nor consider cross-country marriage markets, where people can move from one country to another as marriage migrants.

We use a simple model instead of more elaborate ones because the main purpose of our model is not to theoretically contribute to the literature but to provide an economic framework that guides us to analyze datasets empirically. Note that existing research already provides a theoretical analysis of the interplay between educational choice and household formation in a closed economy (e.g., Iyigun and Walsh (2007)), and the crosscountry marriage markets can be modeled using a standard international trade model with differentiated products (Krugman (1979)).

It is worth noting that the main implications of our model remain the same even if we use an alternative assumption regarding preferences of $L$-type men and women or foreigners, or if we allow native women to bring in a spouse from outside their home country.

\section{Empirical Analysis}

This section aims to examine the implications of our theoretical model, using datasets from Japan, Korea, Taiwan, and Singapore. In our empirical analysis, we use a person's educational attainment as a proxy for his/her socioeconomic status. Particularly, we consider a person who had a tertiary education as $H$-type and the rest as $L$-type. The availability of data substantially varies by country and the type of information. Therefore, we classify our model implications into three groups, explain the data we use, and test model implications in each group.

\subsection{Prevalence of Foreign Spouses, Gender Gap, and Singlehood}

For Japan, Korea, Singapore and Taiwan, we compile a dataset based on aggregate statistics from census and marriage records between 1990 and 2010. Table 1 presents summary statistics from our data. In each census year, we report the fraction of foreigners among newlywed brides and grooms (columns 1 and 2). We then report some statistics 
from our dataset, regarding the marriage market conditions for each year and country. To understand the conditions of a marriage market, we focus on individuals whose age is between 20 and 39 because they are presumably actively participating in the marriage market.

\section{Prevalence of Cross-Border Marriages: Foreign Brides vs. Foreign Grooms}

Column 2 of Table 1 reports the fraction of foreigners among brides who got married in each census year. The importance of foreign brides significantly increases over time in all countries except for Taiwan. The statistics from Taiwan require some explanation. First, due to data availability, the statistics reported in Panel $D$ exclude brides from Mainland China, H.K. and Macao due to data availability (see details in Section 2.4 of Appendix). Second, the decrease in the importance of foreign brides in 2005 and 2009 is due to immigration policy changes. In particular, the Taiwanese government imposed stricter restrictions regarding marriage migrants in response to the public outrage over foreign brides (Seol et al. (2009)). Before the policy change was introduced, the fraction of foreigners among brides had continually increased (Figure A.1 of Appendix).

The prevalence of foreigners among grooms is much lower than that of foreign brides. However, as our model predicted (I.1 in Section 3.2), the two variables are positively correlated and significant. We regress the fraction of native grooms who have a foreign bride on that of native brides who have a foreign groom and dummies of countries. A 1 percentage-point increase in the fraction of native brides who have a foreign groom is correlated with a 2.9 percentage-point increase in the fraction of native grooms who have a foreign bride, and the coefficient is different from zero at the 1 percent level (see Section A of Online Appendix). ${ }^{11}$

\section{Gender Gap in Education and Demand for Foreign Spouses}

Column 3 of Table 3 reports the fraction of college educated men among men aged between 20 and 39, and column 4 reports a measure of gender gap between men's educational attainment and women's. The value in the first row (i.e., -1.6) means that the fraction of college educated among women is 1.6 percentage points higher than that of

\footnotetext{
${ }^{11}$ Online Appendix is available at www.soohyunglee.com/research.
} 
men. In all countries, the gender gap has been decreasing over time. Our model implies that the gender gap is negatively correlated with the fraction of native men marrying a foreign bride, which we find in the data. As the fraction of women with a college degree exceeds that of men by 1 percentage point relative to a previous year, the number of men who marry a foreign bride increases by 0.7 percentage points, and this positive correlation is significant at the 5 percent level (see Table O.1 of Online Appendix).

\section{Education and Singlehood}

Our model implies that women with tertiary education are more likely to remain single than women without tertiary education (I.2 of Section 3.2). To test this implication, we compute the fraction of singles among women whose age is between 30 and 39 depending on their educational attainment. Note that we take this age group because, in this age group, people are assumed to finish all their educational attainment, and the average age of a first marriage is the late 20s. Our result is robust to the age criteria we use (e.g., using 35 or 40 instead of 30). We take the difference in that fraction between college educated women and the rest. The positive values in column 6 of Table 1 means that a larger fraction of college educated women remain single after age 30 compared to women without tertiary education. In all countries and census years, we find that a college graduate woman is significantly more likely to remain single.

As for men, our model assumes that men with high socioeconomic status are more popular among women than their counterparts with low socioeconomic status. This implies that, all else being equal, a highly educated man is more likely to get married than a man with less education. In column 5, we report the difference in the fraction of single men among college-educated men and the rest. A negative figure means that on average a college-educated man is more likely to get married than a man without tertiary education, consistent with our model implication.

\section{Raw Sex Ratio and Demand for Foreign Brides}

Some readers may suspect that sex ratio imbalance may account for the increasing representation of foreigners among brides, but this explanation is not supported by our data. As shown in column 7 of Table 1, raw sex ratios, the number of citizen men per 100 citizen women in that age group, remain stable over time or have the opposite time trend. The 
decrease in sex ratios means that, all else being equal, a man will be in a better position for finding a spouse in his marriage market; therefore, raw sex ratios should be positively correlated with the demand for foreign brides. However, column 7 shows that over the period of a significant increase in foreigners among brides, sex ratios are either not correlated or negatively correlated with the demand (see Table O.1 of Online Appendix for details).

Some sociologists argue that the importance of foreign brides is accounted for by the regional variation of sex ratio (Morgan and Hoffmann (2007)). It is true that in a given year, a man residing in a location with a sex ratio imbalance (e.g., a famer in a rural area) is more likely to marry a foreign woman. However, we find that the fraction of single men who live in such an area decreased over time, while the prevalence of foreign brides increased. Therefore, the sex-ratio imbalance hypothesis cannot explain the time trend, although it may explain the allocation of foreigners across regions in a given year.

\subsection{Education and Likelihood of Having a Foreign Spouse}

Our model implies that, for men, a person with low socioeconomic status has a greater chance of marrying a foreign spouse. To test this implication, we use administrative datasets of marriage records from Japan (2000 and 2005) and Korea (2004 and 2005) (see Section 2 of Appendix for data selection criteria). The marriage records provide the age of the bride and the groom, marital history, employment status, occupation, current location of residence, and citizenship in both countries. By marital history, we mean whether a person had been married prior to his or her current marriage. Korean marriage records additionally collect information about educational attainment, which is not available in Japanese marriage records (see Section B of Online Appendix for detailed summary statistics).

Columns 1 and 2 of Table 4 provide empirical patterns consistent with our hypotheses. For example, in Japan, a man who marries a native wife is more likely to work for a large company, representing high socioeconomic status, than a man who marries a foreign bride. On the contrary, a man who marries foreign wife is more likely to be a production worker than a man who marries a native bride.

The Korean data show the same pattern. The fraction of college graduates is larger among grooms who married another Korean compared to grooms who married a foreign bride. This pattern holds if we consider whether a person is a manager (positively 
correlated with socioeconomic status), or a production worker (negatively correlated with socioeconomic status). ${ }^{12}$

Table 4 Characteristics of Natives Depending on Spouse’s Citizenship

\begin{tabular}{lccccc}
\hline \hline & \multicolumn{2}{c}{ Men } & & \multicolumn{2}{c}{ Women } \\
Foreign Spouse & No & Yes & No & Yes \\
& $(1)$ & $(2)$ & $(3)$ & $(4)$ \\
\hline Japan (2000,2005) & & & & \\
Working for a large firm (\%) & 39.65 & 25.12 & 31.22 & 25.22 \\
Production workers & 21.03 & 28.20 & 7.59 & 9.82 \\
Age & 30.48 & 42.43 & 28.54 & 30.44 \\
Korea (2004,2005) & & & & \\
College educated (\%) & 62.89 & 15.11 & 58.88 & 28.65 \\
Managerial (\%) & 20.43 & 10.07 & 15.02 & 7.13 \\
Production workers & 11.39 & 25.02 & 1.90 & 4.01 \\
Age & 31.28 & 41.01 & 28.80 & 36.50 \\
\hline \hline
\end{tabular}

Certainly, it is possible that some variables that are correlated with men's socioeconomic status (e.g. age) may account for the likelihood of having a foreign bride. To control for such a possibility, we estimate a Probit model in which we regress a dummy indicating whether a groom has a foreign bride on all variables available in each country's marriage records. As shown in Table 5, our observations using Table 4 remain the same. For instance, all else being equal, a high school graduate groom in Korea is 7.6 percentage points more likely to have a foreign bride than his counterpart with a college degree. We conduct various robustness checks using imputed education and income, and our results qualitatively remain the same (see Table O.4 in Online Appendix).

\footnotetext{
${ }^{12}$ It is worth noting that the positive correlation between a man's socioeconomic status and the probability of marrying a foreign bride is not driven by the differential selection into marriage. As we discuss in Section 4.1, a man with high socioeconomic status is more likely to get married. If difference in marriage rate plays an important role, then it implies that more men with low socioeconomic status would have married a foreign bride.
} 
Table 5 Likelihood of Having a Foreign Spouse

(Probit Model: Marginal Effect)

\begin{tabular}{lcccc}
\hline \hline & \multicolumn{2}{c}{ Native Grooms } & \multicolumn{2}{c}{ Native Brides } \\
& Japan & Korea & Japan & Korea \\
& $(1)$ & $(2)$ & $(3)$ & $(4)$ \\
\hline Age & $0.002^{* * *}$ & $0.007^{* * *}$ & $0.0003^{* * *}$ & $0.002^{* * *}$ \\
Ever married & $(0.000)$ & $(0.000)$ & $(0.00001)$ & $(0.000)$ \\
& $0.008^{* * *}$ & $-0.019^{* * *}$ & $0.0005^{*}$ & $0.016^{* * *}$ \\
High school & $(0.000)$ & $(0.001)$ & $(0.0003)$ & $(0.001)$ \\
& - & $0.076^{* * *}$ & - & $0.013^{* * *}$ \\
Middle school or less & & $(0.001)$ & & $(0.000)$ \\
Managerial job & - & $0.165^{* * *}$ & - & $0.041^{* * *}$ \\
& & $(0.003)$ & & $(0.002)$ \\
Service and retailer sector & $-0.004^{* * *}$ & $-0.010^{* * *}$ & $0.0007^{* *}$ & $0.004^{* * *}$ \\
Agricultural sector & $(0.000)$ & $(0.001)$ & $(0.0003)$ & $(0.001)$ \\
& $\left(0.001^{* * *}\right.$ & $0.005^{* * *}$ & $0.002^{* * *}$ & $0.026^{* * *}$ \\
Production job & $0.006^{* * *}$ & $(0.001)$ & $(0.0003)$ & $(0.001)$ \\
& $(0.001)$ & $(0.003)$ & $-0.005^{* * *}$ & $-0.012^{* * *}$ \\
Military/Security service & $0.010^{* * *}$ & $0.012^{* * *}$ & $0.004^{* * *}$ & $0.028^{* * *}$ \\
& $(0.001)$ & $(0.001)$ & $(0.0004)$ & $(0.002)$ \\
Not working - Student & $-0.010^{* * *}$ & $-0.035^{* * *}$ & $-0.003^{* * *}$ & 0.005 \\
& $(0.000)$ & $(0.001)$ & $(0.001)$ & $(0.006)$ \\
Not working - Non-student & - & $0.039^{* * *}$ & - & $0.043^{* * *}$ \\
& $-0.019^{* * *}$ & $-0.019^{* * * *}$ & $-0.024^{* * *}$ & $0.002^{* * *}$ \\
Large firm & $(0.000)$ & $(0.001)$ & $(0.0002)$ & $(0.000)$ \\
& $-0.011^{* * *}$ & - & $-0.002^{* * *}$ & \\
\hline Pseudo R-sq & $(0.000)$ & & $(0.0002)$ & \\
No. obs. & 0.17 & 0.30 & 0.01 & 0.16 \\
\hline \hline & $1,455,349$ & 534,327 & $1,415,946$ & 501,575 \\
\hline
\end{tabular}

Note: Standard errors are in parentheses. The omitted categories are "junior college or more" for education and "white collar" jobs for occupation. Year dummy variables are included. Large firms include those working for a firm that employs 100 or more workers or those who are in management. Low-skilled job refers to production workers for Japan. Not working includes both students and non-students who do not have a job for Japan. The asterisks *, **, and *** indicate statistical significance at the $10 \%, 5 \%$, and $1 \%$ levels, respectively.

\section{Discussion}

In this section, we conduct additional empirical analyses that are not directly related to our model predictions but have important economic and policy implications. The first question is what countries send their women as female marriage migrants to the developed countries in East Asia. This analysis will help us predict "at risk" countries if other countries face a demand for foreign brides. The second question is what types of women become marriage 
migrants and how they differ from their counterparts in their home countries. The third question is whether there is any systematic pattern among native men in terms of choosing the country from which they bring their wives. Finally, we compare female marriage migration with male marriage migration in the East Asian countries.

\subsection{Source Countries of Female Marriage Migrants}

Panel $A$ of Table 6 shows the three major countries that send a large number of female marriage migrants to Japan, Korea, and Taiwan. For all three countries, all major countries are those that are located near and have lower GDP per capita than the corresponding country.

There are many variables correlated with GDP per capita. Thus, we conduct a regression analysis in the spirit of the gravity models used in international trade literature. We compile a cross-country dataset of 193 potential countries from which a country of interest could bring a foreign bride or groom. We estimate a Tobit model where dependent variable is the logarithm of the number of foreign brides who came from a corresponding

Table 6 Major Source Countries of Foreign Spouses

\begin{tabular}{lccc}
\hline \hline & $(1)$ & $(2)$ & $(3)$ \\
\hline \multirow{4}{*}{ Japan } & Panel A. Source of Female Marriage Migrants \\
& China & Philippines & Korea \\
\multirow{3}{*}{ Korea } & $(38.1)$ & $(32.1)$ & $(21.2)$ \\
& China & Vietnam & Philippines \\
Taiwan & $(71.5)$ & $(12.8)$ & $(3.6)$ \\
& China & Vietnam & Indonesia \\
& $(45.6)$ & $(35.4)$ & $(8.2)$ \\
\multirow{4}{*}{ Japan } & & & \\
& Panel B. Source of Male Marriage Migrants \\
Korea & Korea & U.S. & China \\
& $(41.9)$ & $(18.5)$ & $(11.2)$ \\
Taiwan & China & Japan & U.S. \\
& $(41.8)$ & $(31.2)$ & $(11.1)$ \\
& Japan & Thailand & U.S. \\
& $(23.4)$ & $(13.1)$ & $(12.4)$ \\
\hline \hline
\end{tabular}

Note: The table reports the top three countries for foreign brides or foreign grooms.

Numbers in parentheses refer to the number of individuals from the corresponding country divided by the total number of foreign spouses. Source: Marriage records - Japan $(2000,2005)$, Korea $(2004,2005)$, and Taiwan $(2004,2005)$. see details in Section 2 of Appendix.

country in 2005. Note that the dependent variable is censored at zero. We uses the difference in GDP per capita between a country of interest $H \in\{$ Korea, Japan, Taiwan $\}$ and 
a potential trading partner for marriage migration $S$. For flexible specification, we use two variables: $\left|\ln \mathrm{Y}^{\mathrm{H}}-\ln \mathrm{Y}^{\mathrm{S}}\right|+$ is the absolute value of the per capita GDP gap between the two countries if the destination country $H$ is more developed than country $\mathrm{S}$, and zero otherwise. Likewise, $\left|\ln \mathrm{Y}^{\mathrm{H}}-\ln \mathrm{Y}^{\mathrm{S}}\right|$ - is the absolute value of per capita GDP gap if country $\mathrm{S}$ is more developed than country $H$, and zero otherwise. We also control for geographical distances between two countries, and bilateral trade volume (sum of import and export) to proxy for a cultural and economic proximity. ${ }^{13}$

Table 7 Source Countries of Foreign Spouses, Japan, Korea and Taiwan Pooled

\begin{tabular}{lcccccc}
\hline Dep. Var. & \multicolumn{3}{c}{ Log (Brides) } & \multicolumn{3}{c}{ Log (Grooms) } \\
& $(1)$ & $(2)$ & $(3)$ & $(4)$ & $(5)$ & $(6)$ \\
\hline$\left|\ln \mathrm{Y}^{\mathrm{H}}-\ln \mathrm{Y}^{\mathrm{S}}\right|+$ & -0.495 & $1.793^{* * *}$ & $2.249^{* * *}$ & $-1.625^{* *}$ & $1.120^{*}$ & 0.782 \\
& $(0.608)$ & $(0.645)$ & $(0.712)$ & $(0.694)$ & $(0.639)$ & $(0.681)$ \\
$\left|\ln \mathrm{Y}^{\mathrm{H}}-\ln \mathrm{Y}^{\mathrm{S}}\right|-$ & 2.709 & 1.083 & 0.447 & $4.818^{* *}$ & 2.994 & $3.734^{*}$ \\
& $(2.457)$ & $(2.348)$ & $(2.369)$ & $(2.311)$ & $(2.120)$ & $(2.234)$ \\
$\ln$ (Trade) & - & $2.116^{* * *}$ & $2.105^{* * *}$ & - & $3.113^{* * *}$ & $3.140^{* * *}$ \\
& & $(0.407)$ & $(0.389)$ & & $(0.588)$ & $(0.583)$ \\
$\ln$ (Distance) & $-8.685^{* * *}$ & $-3.842^{* * *}$ & $-2.917^{* * *}$ & $-6.646^{* * *}$ & -0.035 & -0.650 \\
& $(1.432)$ & $(1.023)$ & $(1.206)$ & $(1.378)$ & $(1.041)$ & $(1.183)$ \\
\hline Region Dummy & No & No & Yes & No & No & Yes \\
\% with Non Zero & 8.23 & 8.23 & 8.23 & 7.74 & 7.74 & 7.74 \\
No obs. & 462 & 462 & 462 & 462 & 462 & 462 \\
PseudoR2 & 0.26 & 0.26 & 0.29 & 0.14 & 0.31 & 0.34 \\
\hline \hline
\end{tabular}

Note: The unit of observations is country. Heteroskedasticity robust standard errors are reported in parentheses. Pooled regression model includes host country dummy variables. Region dummy variables are defined for 6 regions: East Asia and Pacific, Europe and Central Asia, Latin America and Caribbean, Middle East and North Africa, South Asia and Sub-Saharan Africa.

In Table 7, we report our estimation results based on a pooled sample of Japan, Korea, and Taiwan. The results are consistent with our model prediction. The gap in GDP per capita between the destination country $H$ and country $S$ is positively correlated with the number of women a country sends as marriage migrants to a developed East Asian country,

\footnotetext{
${ }^{13}$ For Korea and Japan, we used the World Bank Development Index to collect all variables except for physical distance. For physical distance between two countries, we use a dataset from CEPII. The CEPII provides two measures of distance between the two countries. One is the physical distance between the two capital cities. The other is the population-weighted distance based on multiple locations. We use the first measure because it is available for a large number of countries and is highly correlated with the populationweighted distance. For Taiwan, we gather GDP per capita from the World Bank Development Indicator, trade volume from the Bureau of Foreign Trade of Republic of China and physical distance from GEOBYTE and GlobeFeed.
} 
even after controlling for cultural and economic ties. These findings qualitatively remain the same if we run the regression separately (see Table O.5 of Online Appendix).

After controlling for both trade volume and geographic distance, the lower the GDP per capita, the greater the number of brides the country sends to Japan, Korea or Taiwan. The 10 percent increase in the GDP gap increases the number of brides from the country by about 18 percent (Column 2 of Table 7). The strength of economic ties, approximated by the natural log of trade volume, contributes to increase the flow of brides. On the contrary, geographic distance, approximated by the natural log of distance, decreases the flow of brides. The estimation results do not change even after including 6 regional dummy variables (Column 3 of Table 7).

\subsection{Characteristics of Foreign Brides}

Table 8 reports the average characteristics of brides depending on their nationalities. In both Korea and Japan, foreign brides are substantially different from native brides in terms of socioeconomic status and demography. An interesting finding is that even among foreign brides, there are large differences in brides' characteristics across nationalities. For example, Chinese brides in both countries are on average older and more likely to have a previous marriage than average Vietnamese or Filipino brides. A noticeable pattern is that in Korea, about 11 percent of Vietnamese brides work in the agricultural sector, whereas less than 2 percent of non-citizen brides from China or the Philippines do. It is possible that the observed differences across brides' nationalities can be entirely due to the heterogeneity in their grooms' characteristics, for instance, an old groom marries a Chinese woman, whereas a young groom marries a Vietnamese woman. Our further analysis shows that this is not the case. Specifically, we use an exact matching estimator to control for the differences in groom's characteristics across brides' nationalities. We find that the aforementioned difference across nationalities qualitatively remains the same, although the difference is not as stark as before (see Section E of Online Appendix).

Next we examine non-citizen brides' characteristics compared to those of other women in their home countries. We follow the long discussion in the immigration literature regarding whether immigration causes a "brain drain” or induces more investment in human capital (Commander et al. (2004)). Specifically, we compare the female marriage 
migrants with peers in their home country in terms of education using Korean data because the Japanese marriage records do not contain such information. ${ }^{14}$ We use the latest censuses of China (2005), Vietnam (1999), and the Philippines (2000). ${ }^{15}$ Because some brides from Vietnam and the Philippines were too young to have completed their educational attainment in the census year, we use non-citizen brides who were born before 1980. This restriction allows them to be over 19 years old when the census was carried out. Then, for each of the three countries, we calculate weights such that the weighted distribution of cohorts in the census is the same as that among non-citizen brides from that country. Lastly, we calculate the weighted distribution of women's educational attainment. We find that foreign brides are generally more educated than their counterparts in their home countries. As shown in Table 9, about 87 percent of Chinese brides have a secondary education, whereas 65 percent of women in China of the same age do. The fraction of Chinese brides having a tertiary education, however, is smaller than that of the population as a whole. Using the Kolmogorov and Smirnov test, we find that the distribution of educational attainment among Chinese brides is statistically different from that among the entire population at the 1 percent level. ${ }^{16}$

As for Vietnam, Vietnamese brides are clearly more educated than their counterparts in their home country. They are more likely to have a tertiary education, as well as a secondary education, than women in the general population. The hypothesis that the two groups have the same distribution is rejected at the 1 percent level from the Kolmogorov and Smirnov test.

As for the Philippines, we calculate two types of the weighted distribution of female educational attainment: One is for all women; the other is for women working overseas. For example, about 38 percent of Filipino women have a tertiary education, whereas 49 percent of female overseas workers do. Filipino brides who marry a Korean man are, on average, more educated than both overseas workers and the general population, and these

\footnotetext{
${ }^{14}$ Note that we do not focus on occupation because we do not have a good sense of whether a non-citizen bride is not working because she quit her job as a result of marrying a Korean man or simply because she does not work.

${ }^{15}$ For the 2005 Chinese census, we use the cross-tabulation of sex, age, and educational attainment provided by the National Bureau of Statistics of China. The tabulation reports the number of individuals in each category. The censuses of Vietnam and Philippines are available at IPUMS international.

${ }^{16}$ Our findings remain qualitatively the same if we perform the same analysis based on birth-year groups instead of pooling all the samples into one.
} 
Table 8 Brides’ Characteristics Depending on Their Nationality

Panel A: Japan

\begin{tabular}{lcccccc}
\hline \hline & Japan & China & Philippines & Korea & \multicolumn{2}{c}{ Other } \\
& & & & & Developed \\
& $(1)$ & $(3)$ & $(4)$ & $(5)$ & $(6)$ & $(7)$ \\
\hline No. Newlyweds (unit: thousand) & 1415.95 & 20.72 & 17.47 & 11.56 & 4.18 & 0.49 \\
(\% of all newlyweds) & $(96.30)$ & $(1.41)$ & $(1.19)$ & $(0.79)$ & $(0.28)$ & $(0.03)$ \\
\hline Age & 28.56 & 31.36 & 28.05 & 34.69 & 32.35 & 31.68 \\
Ever married (\%) & 13.92 & 44.31 & 12.34 & 40.36 & 35.27 & 24.07 \\
Not working (\%) & 33.60 & 66.46 & 78.46 & 67.41 & 66.71 & 41.36 \\
Work for a large firm (\%, if working) & 37.17 & 15.28 & 5.00 & 17.52 & 15.45 & 35.44 \\
Occupation (\%, if working) & & & & & & \\
- Professional and managers & 25.09 & 14.03 & 5.85 & 16.85 & 9.27 & 58.60 \\
- Sales and Service & 26.19 & 29.74 & 30.81 & 37.87 & 29.74 & 12.98 \\
- Agriculture & 0.26 & 4.29 & 2.02 & 0.24 & 4.60 & 0.00 \\
- Low-skilled & 11.47 & 34.24 & 56.11 & 22.27 & 47.13 & 12.98 \\
\hline \hline
\end{tabular}

Panel B: Korea

\begin{tabular}{|c|c|c|c|c|c|c|}
\hline & $\begin{array}{c}\text { Korean } \\
\text { (1) }\end{array}$ & $\begin{array}{c}\text { China } \\
\text { (3) }\end{array}$ & $\begin{array}{c}\text { Vietnam } \\
\text { (4) }\end{array}$ & $\begin{array}{c}\text { Philippi } \\
\text { nes } \\
\text { (5) }\end{array}$ & $\begin{array}{c}\text { Other } \\
\text { developing } \\
(6)\end{array}$ & $\begin{array}{c}\text { Developed } \\
\text { (7) }\end{array}$ \\
\hline No. Newlyweds (unit: thousand) & 495.16 & 35.15 & 6.22 & 1.75 & 3.27 & 2.10 \\
\hline (\% of all newlyweds) & $(91.08)$ & $(6.47)$ & $(1.14)$ & $(0.32)$ & $(0.60)$ & $(0.39)$ \\
\hline \% Currently living outside Korea & 0.02 & 97.45 & 97.30 & 95.31 & 94.25 & 92.34 \\
\hline Age & 28.80 & 35.31 & 22.62 & 25.80 & 27.55 & 30.57 \\
\hline Ever married (\%) & 13.54 & 64.77 & 1.52 & 1.46 & 13.86 & 11.45 \\
\hline \multicolumn{7}{|l|}{ Education (\%) } \\
\hline - College or more & 59.89 & 6.88 & 4.46 & 43.25 & 47.81 & 76.27 \\
\hline - High school & 36.52 & 48.25 & 45.88 & 50.41 & 41.34 & 22.27 \\
\hline - Middle school or less & 3.59 & 44.87 & 49.66 & 6.33 & 10.84 & 1.46 \\
\hline \multicolumn{7}{|l|}{ Employment status (\%) } \\
\hline - a white-collar job & 24.68 & 5.96 & 2.01 & 6.78 & 7.01 & 17.57 \\
\hline - a managerial job & 15.04 & 1.45 & 0.71 & 4.30 & 5.40 & 15.12 \\
\hline - the service and retailer sector & 7.74 & 5.68 & 1.62 & 4.42 & 4.82 & 6.63 \\
\hline - the agricultural sector & 0.23 & 1.21 & 11.52 & 0.97 & 2.22 & 0.15 \\
\hline - a low-skilled job & 1.91 & 2.34 & 1.49 & 1.45 & 2.80 & 0.69 \\
\hline - Not working - Student & 2.15 & 0.82 & 1.01 & 1.03 & 4.12 & 7.66 \\
\hline - Not working - Non-student & 48.09 & 82.45 & 81.53 & 80.88 & 73.43 & 51.60 \\
\hline
\end{tabular}


differences are statistically significant at the 1 percent level. These findings suggest that, in terms of educational attainment, non-citizen brides are positively selected from the population.

Table 9 Foreign Brides in Korea and Women in Their Home Country

\begin{tabular}{lccc}
\hline & & \multicolumn{2}{c}{ (unit: Percent) } \\
\hline Panel A. Chinese & Primary & Secondary & Tertiary \\
$\quad$ Brides & & & \\
$\quad$ Population (Women) & 5.78 & 87.26 & 6.96 \\
Panel B. Vietnamese & 27.18 & 64.72 & 8.11 \\
$\quad$ Brides & & & \\
$\quad$ Population (Women) & 6.13 & 85.34 & 8.53 \\
Panel B. Filipino & 35.92 & 57.77 & 6.31 \\
$\quad$ Brides & & & \\
$\quad$ Population (Women) & 1.31 & 46.42 & 52.27 \\
$\quad$ Population (Female overseas workers) & 22.37 & 39.33 & 38.30 \\
\hline \hline
\end{tabular}

\subsection{Men's Choice of Bride’s Nationality}

Given the fact that brides' characteristics vary by their home countries, we study men's choice of their brides' home country. Specifically, we conduct the following thought experiment with a Multinomial Logit model. Consider two grooms who have the same observable characteristics except for one dimension (e.g., age). Would their brides be more likely to come from the same country? We classify brides' home countries into six categories: a groom's home country (i.e., native bride), three major countries sending women to his country, other developing country, and developed country. We then estimate a Multinomial Logit model using the micro-level marriage records in Japan and Korea. As for explanatory variables, we include groom's age and dummy variables for marital history, occupation, and year (and education for Korea).

For expositional simplicity, we report the marginal effects of key variables on the likelihood of marrying a woman from each category in Table 10. Note that all reported marginal effects are significant at the 1 percent level except for the coefficients for "other developed countries” and “developing countries.” Consider “low-skilled job”: Compared to his counterpart with a white-collar job, a Korean groom working in the agricultural sector is 1.87 percentage points more likely to have a Vietnamese bride and 0.51 percentage 
points more likely to have a Chinese bride, instead of a Korean bride. This finding suggests an interesting possibility of positive assortative sorting among cross-border marriages.

Table 10 Choice of Bride’s Nationality Based on Groom’s Characteristics

\begin{tabular}{lcccccc}
\hline \multicolumn{7}{c}{ Panel A: Japan } \\
\hline \hline Japan & China & Philippines & Korea & $\begin{array}{c}\text { Other } \\
\text { developing }\end{array}$ & Developed \\
(Unit: Percentage points) & $(1)$ & $(1)$ & $(2)$ & $(3)$ & $(4)$ & $(5)$ \\
\hline Age & -0.20 & 0.08 & 0.06 & 0.04 & 0.02 & 0.00 \\
Agriculture & -0.90 & 0.51 & 0.19 & 0.09 & 0.11 & -0.00 \\
Low-skilled job & -1.01 & 0.36 & 0.35 & 0.13 & 0.17 & -0.00 \\
Security & 0.96 & -0.34 & -0.29 & -0.27 & -0.06 & 0.00 \\
Not working & 1.81 & -0.74 & -0.57 & -0.39 & -0.13 & 0.03 \\
\hline No obs., Pseudo R-sq & & & $1,470,369$ & 0.13 & & \\
\% obs. (prediction= choice) & & & & 96.27 & & \\
\hline \hline
\end{tabular}

Panel B: Korea

\begin{tabular}{lcccccc}
\hline \hline & Korea & China & Vietnam & Philippines & $\begin{array}{c}\text { Other } \\
\text { developing }\end{array}$ & Developed \\
\cline { 2 - 7 } (Unit: Percentage points) & $(1)$ & $(2)$ & $(3)$ & $(4)$ & $(5)$ & $(6)$ \\
\hline Age & -0.46 & 0.34 & 0.05 & 0.02 & 0.04 & 0.01 \\
High school & -6.55 & 5.13 & 0.87 & 0.26 & 0.45 & -0.16 \\
Middle school or less & -14.81 & 11.45 & 1.90 & 0.81 & 0.87 & -0.22 \\
Agriculture sector & -4.00 & 0.51 & 1.87 & 0.67 & 0.92 & 0.03 \\
Low-skilled job & -0.60 & 0.33 & 0.08 & 0.07 & 0.18 & -0.06 \\
Not working - Student & 2.99 & -1.95 & -0.35 & -0.14 & -0.42 & -0.13 \\
Not working - Non-student & 1.30 & -1.09 & -0.19 & -0.03 & -0.15 & 0.16 \\
\hline No obs., Pseudo R-sq & & & & 534,327 & 0.27 & \\
\% obs. (prediction = choice) & & & & 91.55 & & \\
\hline \hline
\end{tabular}

Note: This table reports the marginal effects of the multinomial logit regression. We additionally include dummy variables for occupation, year, and region for Korea, and a dummy variable for year for Japan. Consider Panel A. Among Korean grooms, a one-year increase in the age of a groom is associated with 0.34 percentage-point increase in the likelihood of marrying a Chinese bride, a 0.05 percentage-point increase in the likelihood of marrying a Vietnamese bride, and so on, while it decreases the likelihood of marrying a Korean bride by 0.46 percentage points.

In Korea, the number of Vietnamese brides is less than 20 percent of that of Chinese. However, the marginal effect of being an agricultural sector worker on having a Vietnamese bride (11.5 percent) exceeds that of Chinese (1.2 percent). This means that a Korean groom working in the agricultural sector is much more likely to have a Vietnamese 
bride instead of a Chinese bride. One possible explanation for this finding is that the fraction of Vietnamese women who work in the agricultural sector in their home country is much larger than that of Chinese women. For instance, a Korean farmer may take a Vietnamese bride who will be more helpful to his farming production than a Chinese bride. A similar pattern is observed for Japan. A Japanese groom with a low-skilled occupation is more likely to have a Chinese bride instead of a Japanese bride by 0.36 percentage points compared to his counterpart clerical worker. The former's likelihood of having a Filipino bride instead of a Japanese bride is 0.35 percentage points higher than the latter. Because there are more Chinese brides than Filipino brides in Japan, a groom with a low-skilled job is more likely to have a Filipino bride. The fraction of low-skilled job workers is 44.0 percent among Filipino brides and 22.8 percent among Chinese brides. This may account for the fact that a low-skilled groom is more likely to have a Filipino bride more often instead of Chinese.

Overall, the analysis of grooms' choice of brides' nationality indicates that grooms with lower socioeconomic status tend to marry brides from developing countries. This evidence offers additional support for our theory that lower SES men in developed countries marry women from developing countries.

\subsection{Comparison between Male Marriage Migration and Female Marriage Migration}

This section examines the extent to which male marriage migration in East Asia is similar to the female marriage migration that we have studied so far. We first examine the countries from which the majority of male marriage migrants (e.g., foreign brooms) come. As shown in Panel B of Table 6, a noticeable difference between the major home countries of female and male marriage migrants is that each of these three countries has a significant number of grooms from other developed countries, such as the U.S. (for all three countries) and Japan (for Korea and Taiwan). Recall that for female marriage migrants, the major source countries have a lower GDP per capita than a corresponding country.

To formally test this observation, we estimate a Tobit model, regressing the logarithm of the number for male marriage migrants on explanatory variables. Column 4 of Table 7 shows that, conditional on the geographical distance, when a country has a larger GDP per capita than Japan, Korea, and Taiwan, a greater number of native women marry a 
man from that country (e.g., male marriage migrants). When we control for trade volumes between the two countries (columns 5 and 6), there is only a weak correlation between the GDP per capita gap, which is the opposite of our findings for female marriage migrants, which is different from our results on female marriage migrations.

Why do we find a positive correlation between the GDP per capita gap and the number of female marriage migrants, but no correlation between the GDP per capita gap and the number of male marriage migrants? Regarding female marriage migrations, the GDP per capita can be positively correlated to both groom's and bride's gains from marriage. From a marriage migrant's perspective, the GDP per capita difference between a host country and the migrant's home country can be a proxy for the gains from marriage migration because he/she can expect a higher living standard and send a larger amount of remittances to his/her own family back in the source country.

Next consider a native man who considers a woman from country $A$ and another woman from country $B$. Suppose that the GDP per capita gap between the man's country and $A$ is larger than that between his country and country $B$. The native man may prefer the woman from country $A$ (less developed than country $B$ ) because he can gain more bargaining power and thus transfer less amount of income to his spouse. Therefore, the GDP per capita gap can be positively correlated with the gains from marriage of both native men and potential female migrants.

In contrast, for a native woman's perspective, marrying a person from less developed country (thus large GDP per capita gap) can be negatively correlated with her gains from marriage. In the East Asian countries, there exists relatively large gender gap in labor markets (measured by labor market participation rate and wage gap). Therefore, a husband's income, instead of wife's, can largely determine the total gains from marriage (that is the sum of the net gains from marriage to a husband and wife). If it is the case, then marrying a man from a less-developed country implies that the total gains from marriage will be low, which can dominate the benefit that a native woman may have by having a stronger bargaining power.

We next examine the common characteristics of brides who have a foreign groom, doing the same type of analysis as in Section 4.2. We estimate a Probit model regressing an indicator of having a foreign broom on native brides' observable characteristics. Just as we 
found for native grooms, older and less educated women are on average more likely to have a foreign groom (columns 3 and 4 of Table 5). However, opposite from our findings in terms of likelihood of having a foreign bride, we find that compared to a woman with a white-collar job, a managerial worker is more likely to have a foreign groom and a woman in the agricultural sector is less likely to have a foreign groom. We think that this opposite pattern occurs because two types of native brides have a foreign groom: One type, the majority, has low socioeconomic status; the other does not. For example, in Korea, 47 percent of brides who have a groom from another developed country are college educated, whereas less than 6 percent of brides who have a Chinese groom are college educated. Thirteen percent of brides who have a groom from developed countries have a managerial job, whereas 9 percent of brides who have a Chinese groom have one.

These findings imply that, different from native grooms, brides who have a foreign groom are more diverse, and, among them, women with a higher socioeconomic status have a groom from another developed countries instead of having a groom from less developed country.

\section{Conclusion}

This paper documents a recent yet significant international marriage migration commonly observed in developed East Asian countries. Using an economic framework, we explain that such a phenomenon is due to both female advancements in educational attainment and cultural norms, making marriage less attractive to educated women. Using datasets from Japan, Korea, Singapore, and Taiwan, we conduct micro and macro empirical analyses, whose results support our theoretical model.

This paper naturally raises various research questions. How does the large influx of marriage migrants affect natives' marriage opportunity, marriage surplus, and divorce? To what extent will a cross-border marriage be similar to a marriage between two natives in terms of fertility, dissolution, and bargaining power? How does sending a large number of women to other countries as brides affect the brides' home country, for example, through changing sex ratio and remittances?

Another importance future research topic is the international impact of the Chinese

skewed sex ratio. The results from this paper suggest that as China becomes more 
developed, the direction of marriage migration will significantly change, as follows. First, the supply of Chinese women to the currently developed East Asian countries will decrease as the development gap between those countries and China narrows. This is because the gains from marriage migration will become smaller to a Chinese woman. Second, the raw and effective sex ratio imbalance, together with rapid Chinese growth, will lead to a large demand for brides outside China. Our results suggest that countries that are located near China, are less developed, and have close economic ties with China, such as Cambodia and Vietnam, will be “at risk” for a large volume of female outflow to China though marriage.

\section{References}

Abramitzky, Ran; Adeline Delavande and Luis Vasconcelos. 2011. "Marrying Up: The Role of Sex Ratio in Assortative Matching." American Economic Journal: Applied Economics, 3(3), 124-57.

Angrist, Joshua. 2002. "How Do Sex Ratios Affect Marriage and Labor Markets? Evidence from America's Second Generation." Quarterly Journal of Economics, 117(3), 997-1038.

Becker, Gary S. 1973. "A Theory of Marriage: Part I." Journal of Political Economy, 81(4), 813-46.

Chiappori, Pierre-André; Murat Iyigun and Yoram Weiss. 2009. "Investment in Schooling and the Marriage Market " American Economic Review, 99(5), 1689-713.

Commander, Simon; Mari Kangasniemi and L. Alan Winters. 2004. "The Brain Drain: Curse or Boon? A Survey of the Literature," R. E. Baldwin and L. A. Winters, Challenges to Globalization: Analyzing the Economics. University of Chicago Press,

Edlund, Lena. 1999. "Son Preference, Sex Ratios, and Marriage Patterns." Journal of Political Economy, 107(6), 1275-304.

Fernández, Raquel; Alessandra Fogli and Claudia Olivetti. 2004. "Mothers and Sons: Preference Formation and Female Labor Force Dynamics." Quarterly Journal of Economics, 119(4), 1249-99.

Fisman, Raymond; Sheena S. Iyengar; Emir Kamenica and Itamar Simonson. 2006.

"Gender Differences in Mate Selection: Evidence from a Speed Dating Experiment." Quarterly Journal of Economics, 121(2), 673-97.

Foster, Andrew D. and Mark R. Rosenzweig. 2001. "Missing Women, the Marriage Market and Economic Growth," Brown University and University of Pennsylvania, Goldin, Claudia. 2006. "The 'Quiet Revolution' That Transformed Women's Employment, Education, and Family." American Economic Review, Papers and Proceedings, 96(2), 1-21. Hitsch, Günter. J.; Ali Hortaçsu and Dan Ariely. 2010. "Matching and Sorting in Online Dating Markets." American Economic Review, 100(1), 130-63.

Iyigun, Murat F. and Randall Phillip Walsh. 2007. "Building the Family Nest: Premarital Investments, Marriage Markets, and Spousal Allocations." Review of Economic Studies, 74(2), 507-35. 
Korea, Presidential Committee on Social Inclusion in South. 2005. " International Marriage Brokerage System - the Case Study of Vietnam and Philippines," Policy Report. Krugman, Paul R. 1979. "Increasing Returns, Monopolistic Competition, and International Trade " Journal of International Economics, 9(4), 469-79.

Lafortune, Jeanne. 2011. "Making Yourself Attractive: Pre-Marital Investments and the Returns to Education in the Marriage Market," University of Maryland.

Lee, Hye-Kyung. 2008. "International Marriage and the State in South Korea: Focusing on Governmental Policy." Citizenship Studies, 12(1), 107-23.

Lee, Soohyung. 2011. "Marriage in Online Dating Services," mimeo, University of Maryland.

Lee, Soohyung and Muriel Niederle. 2011. "Propose with a Rose? Signaling in Internet Dating Markets," NBER working paper \#17340.

Lundberg, Shelly and Robert Pollak. 2007 "The American Family and Family Economics." Journal of Economic Perspectives, 21(2), 3-26.

Morgan, Charlie V. and John P. Hoffmann. 2007. "International Marriages in Japan: A Prefecture-Level Analysis." International Journal of Sociology and the Family, 33(1), 15782.

Nielsen, Helena; Nina Smith and Aycan Celikaksoy. 2009. "The Effect of Marriage on Education of Immigrants: Evidence from a Policy Reform Restricting Spouse Import." The Scandinavian Journal of Economics Volume, 111(3), 457-86.

Roth, Alvin E. and Marilda Sotomayor. 1990. Two-Sided Matching: A Study in GameTheoretic Modeling and Analysis. Cambridge: Cambridge University Press.

Sato, Kunio. 1988. "Wives for Farmers: A Critical Import." Japan Quarterly, 28, 253-59. Seol, Dong-Hoon; Moon-Hee Suh; Sam-Sic Lee and Myoung-Ah Kim. 2009. "A Study of the Medium- to Long-Term Prospects and Measures of Multicultural Family in Korea: On the Focus of the Population Projection of Multicultural Family in Korea, and the Analysis of Its Socio-Economic Impacts on Korean Society," Policy Report, Korea Ministry of Health, Welfaure and Family Affairs.

Wang, Hong-zen and Shu-ming Chang. 2002. "The Commodification of International Marriages: Cross-Border Marriage Business in Taiwan and Viet Nam." International Migration, 40(6), 93-116.

Wei, Shung-Jin and Xiaobo Zhang. 2011. "The Competitive Saving Motive: Evidence from Rising Sex Ratios and Saving Rates." Journal of Political Economy, 119(3), 511-64 Weiss, Yoram. 2000. "Economic Theory of Marriage and Divorce," N. J. Smelser and P. B. Baltes, International Encyclopedia of Social and Behavioral Sciences. Elsevier, Yang, Wen-Shan and Melody Chia-Wen Lu eds. 2010. Asian Cross-Border Marriage Migration. Amsterdam: Amsterdam University Press.

\section{Appendix}

\section{Proof of Theorem 1}

Remark 1 implies that the number of men marrying a foreigner is the same as the number of modern $H$-type women remaining single. With this implication in hand, let us examine stable matchings. In this marriage market, modern $H$-type men are the men most preferred 
by women. Therefore, in any stable matching, these men will marry their first choice-that is, a modern $\mathrm{H}$-type woman-as long as there is a large enough supply of this type of women. Suppose that $\alpha_{m} h_{m}$ is greater than or equal to $\alpha_{w} h_{w}$. Then, all modern $H$-type women have a modern $\mathrm{H}$-type husband. Therefore, no modern $\mathrm{H}$-type woman remains single. Given the preferences of natives, this means that no man will have a foreign bride.

Alternatively, suppose that $\alpha_{m} h_{m}$ is less than $\alpha_{w} h_{w}$. Then, only $\alpha_{m} h_{m}$ number of modern $H$-type women marry modern $H$-type men and the rest $\left(\alpha_{w} h_{w}-\alpha_{m} h_{m}\right)$ need to marry a native man other than $H$-type or remain single. Recall that among the remaining native men, all men prefer the modern $H$-type women the least, and all women prefer a traditional $H$-type man to $L$-type. Therefore, the remaining modern $H$-type women cannot marry a traditional $\mathrm{H}$-type man and thus remain single. Combining these two results, the number of men who marry a foreigner is $\max \left(0, \alpha_{w} h_{w}-\alpha_{m} h_{m}\right)$.

\section{Data}

\subsection{Japan}

We use the “Employment Status Survey (1992, 1997, 2002, 2007)” published by the Japanese Ministry of Internal Affairs and Communications to calculate sex ratio and educational attainment among people aged 20 to 39. "College degree” means a degree from a 2-year or 4-year college or polytechnic called Kosen. We use the corresponding marriage records from the vital statistics to calculate the fraction of foreigners among brides or grooms. By "foreigners," we mean persons who do not hold Japanese citizenship. We obtain micro-level datasets of marriage records for 2000 and 2005. These two years are selected because occupational information is recoded in years ending with 0 or 5 .

\subsection{Korea}

We use the Korean Population Census to construct educational attainments and sex ratios among people whose age is between 20 and 39; the data are available on the website of the Korean National Statistical Office (www.kosis.go.kr). We define a person as college educated if he/she attended or has a degree from a university (4-year) or 2-year college (called Junmoondaehak).

We use the Korean marriage records, released as a part of "National Population and 
Fertility Survey.” We regard a person as a marriage migrant if he/she currently resides outside South Korea and his/her bonjeok is outside South Korea. A person's bonjeok roughly refers to the geographical location where the person is originally from. For example, consider a person who currently lives in Seoul but grew up in China. The person's bonjeok is China. As for our micro-level analysis, we only use the marriage records for 2004 and 2005, although we could extend our sample to other years of marriage records for the following reasons. The Korean Statistical Office changed its classification of countries in 2004. Fewer than 10 categories of countries were used in marriage records prior to 2004, while marriage records from 2004 onward report the name of the country that a bride/groom resides in and has citizenship from. Importantly, some countries that sent a large number of women to Korea as brides (e.g., Vietnam and Philippines) were classified as “others” prior to 2004. Therefore, we choose marriage records from 2004 onward for comparability in some of our analyses (e.g., brides' characteristics depending on their home countries). We then limit our analysis to marriage records for 2004 and 2005 because our Japanese datasets are available up to 2005. Note that our empirical analyses, such as the characteristics of grooms who have a foreign bride, qualitatively remain the same when we include the marriage records from 1998 to 2003.

\subsection{Singapore}

We use the Singaporean Population Census (2000 and 2010, Education of "Resident Nonstudent Population”) to compute the educational attainment and sex ratio for individuals aged 20 to 39. Following the Census classification, we regard a person as having a college education if he/she has a diploma from a university, polytechnic, or an equivalent institution. To compute the fraction of singles depending on sex and tertiary education, we combine the population census and tables from "Population in Brief 2010” published by the Singapore Department of Statistics. "Population in Brief 2010” provides a table reporting the fraction of people who remain single depending on multiple levels of educational attainment, as of 1999 and 2009. We assume that the distribution of educational attainment in 1999 (2009) is the same as that in 2000 (2010). For each year, we then compute the fraction of singles among college educated men (women) and among non-college educated men (women). We refer to "Statistics on Marriages \& Divorces 2009," published by the 
Singapore Department of Statistics in 2010, to report the prevalence of cross-border marriages. We consider a person as a marriage migrant if he/she did not have citizenship or permanent residency in Singapore but married a Singaporean citizen or permanent resident.

\subsection{Taiwan}

We use the statistics of age- and sex-specific educational attainment of Taiwanese people provided by the Taiwanese Ministry of Education. Using these statistics, we compute the fraction of college educated among individuals whose age is between 20 and 39 and the sex ratio. We consider a person as having a tertiary education if he/she graduated from or attended a 2-year or 4-year college.

We use the tables from "Marriage Registrations," available from the Taiwanese National Statistics Bureau. Note that the Taiwanese government classifies a person as a "foreigner" if the person is neither overseas Taiwanese nor Chinese from Mainland China, Hong Kong, or Macao. The information on the fraction of Taiwanese grooms/brides who have a spouse from a foreign country, as defined by the Taiwanese government, is available from 1998, but the fraction of Taiwanese grooms/brides who married Chinese from Mainland China, Hong Kong, or Macao is available from 2004.

Figure A.1 Taiwan: Prevalence of Marriage Migrations

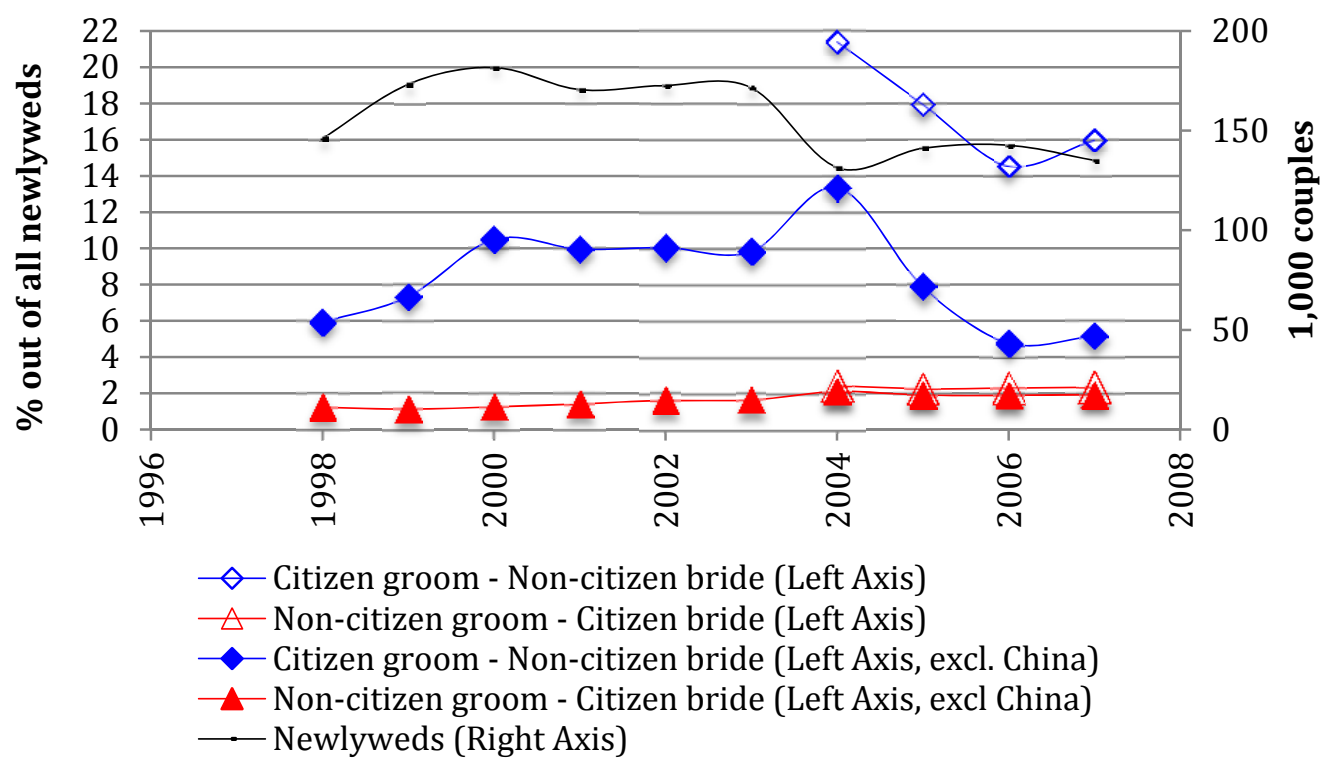


However, as shown in Figure A.1, the two series are highly correlated. For example, the blue line marked with solid diamonds shows the fraction of Taiwanese grooms having a bride who is a foreigner according to the Taiwanese government's definition, whereas the blue line marked with empty diamonds shows the fraction of Taiwanese grooms having a bride from a country other than Taiwan, following our definition of foreigners. Although the magnitudes are different, they are almost identical in terms of time trend. As for women, the fraction of Taiwanese who married a foreigner (red line marked with solid triangles) is almost identical to the fraction of Taiwanese women who married a man from a country other than Taiwan (red line marked with empty triangles). 